Dubovyk Nataliya,

Phd Political Sience

ORCID: 0000-0003-0151-9480

Kyryliuk Natalia,

Phd Political Sience,

State University of Telecommunications, 03680, Kyiv, Solomenska street, Ukraine

ORCID: 0000-0003-0379-3707

\title{
PROBLEMATIC ISSUES OF STATE COMMUNICATION IN UKRAINE
}

Every year new information reality is becoming more and more evident, which is manifested in wide access to various information, knowledge, messages and so on.Along with the information space, an important aspect of globalization is presented by the communicative space, in which an important role is attributed to political communication as a dialogue between states and as an interstate communication interactions that influence the global political process. Searching for effective ways of communication policy implementing and consistent actions in systematic implementation of constructive decisions of state communication implementation, development of legislative acts of communication and state policy will give an opportunity to effectively move towards positive changes. Thus, the most important things are: systematic implementation of changes starting from the state constitution in the field of communication management; verbal image of the government official, his linguistic communication to gain the trust of the society; clear explanation of the decisions and reforms that will lead to overall well-being and global recognition.

Key words: communication, political communication, state communication, public communication.

\section{Дубовик Наталія, Кирилюк Наталія. Проблемні питання державної комунікації в Украӥні.}

3 кожним роком все більш стає відчутною нова інформаційна реальність, що проявляється у широкому доступі до різноманітної інформації, знань, повідомлень тощо. Поряд з інформаційним простором, важливим аспектом глобалізаиії є комунікативний простір, у якому важливу роль відіграє політична комунікаиія, як діалог між державами, так і внутрішньодержавні комунікативні взаємодї, що чинять вплив на світовий політичний процес. Пошук ефективних шляхів здійснення комунікаиійної політики та послідовних дій y системному впроваджені конструктивних рімень здійснення державної 
комунікаиії, розробка законодавчих актів комунікащійної і державної політики наддасть можливість ефективно рухатись у напрямку позитивних зрушень. Найголовнішим повинно стати системне впровадження змін починаючи з конституиї держави у питанні управління комунікаціями; вербального іміджу державного управліния, його мовної комунікаџії для отримання довіри суспільства; чіткого роз 'яснення рімень та реформ, які призведуть до загального добробуту і світового визнання.

Ключові слова: комунікачія, політична комунікачія, державна комунікачія, політична комунікація.

Relevance of the research topic. The changes that are taking place in the modern world are dependent on the practices of global information exchanges and are linked to the globalization trends. Every year new information reality is becoming more and more evident, which is manifested in wide access to various information, knowledge, messages and so on. Even though the combinations of information and telecommunication space dissolve boundaries between states and creates a sense of a single global community, globalization is a contradictory process in political, socioeconomic and cultural life.

Formulation of the problem. Along with the information space, an important aspect of globalization is presented by the communicative space, in which an important role is attributed to political communication as a dialogue between states and as interstate communication interactions that influence the global political process. In general, «communication is a necessary element of interaction between people, groups, nations, states in the transmission of information» (Pryluts'ka et al., 2016, P. 73).

Political communication in Ukraine is sluggish in the absence of a strategy, namely a communication state strategy. Therefore, the issues of identifying and elimination the weaknesses of communication policy, seeking an understanding of the authorities' actions, confidence in them and active communication interaction are relevant, but at the same time are in sufficiently studied.

Analysis of recent studies and publications. The concept of communication began to develop in the early twentieth century. Beginning with the development of the researches of Z. Freud, K. Jung, E. Bern, K. Rogers, Y. Moskovichi, further gaining importance in various concepts, in particular by R. Jacobson, Y. Lotman, U. Ecu, T. Newcom, Marshall McLunan, Daniel Bell, Neil Postman, Tom Stonier, John Broadus Watson, Edward Lee Thorndike. The basis of modern communication policy rests upon the teachings of P. Lazerfeld, G. Alport, W. Schramm, G. Lasswell. The theory of communicative action by J. Habermas and system theory by $\mathrm{N}$. Lumanare considered as unsurpassed in the development of modern theory of communication. 
Among Ukrainian researchers of various aspects the following scientists V. Bebik, V. Bortnikov， M. Vlasenko, N. Gritsyak, L. Degtyareva，O. Zaslavska, S. Zelinsky, S. Zorko, B. Kalinichenko, I. Kolosovska, A. Kudryachenko, Y. Padafet, O. Porfimovich, G. Pocheptsov, M. Sirotich, P. Unguryan, O. Shvets, and others consider in their works the issues of communication, communicative space and communicative politics in general.

Presenting main material. The main objective is to cover the problematic aspects of state communication: lack of systematic approach, linguistic competence of government officials, issues of trust in the authorities and so on. Searching for effective ways of communication policy implementing and consistent actions in systematic implementation of constructive decisions of state communication implementation, development of legislative acts of communication and state policy will give an opportunity to effectively move towards positive changes.

Communication should be understood as means of transmitting information from one person to another, as a social information exchange and, in the broadest sense, as means of connecting all spheres of society.

Communication, as the transmission of information from one person to another, and information as social interchange, consists, in the first place, of a verbal component. When communicating, we exchange ideas, learn, and at the same time, we can bring something new.

However, at the state level, there is no real awareness of the importance of the role of communication in achieving overall well-being and success. Recent political developments in Ukraine (presidential and parliamentary elections) have stirred up the political elite, attracted the attention of the general population, and demonstrated the results of communication policies that are diametrically oppositely evaluated both in the field of professionals and in the society at large.

Political communication is a broader concept of state communication. In terms of understanding the essence of categories, the opinion of modern researcher T. Lomakina is quite correct.

Political communication is first and foremost a governance process in which organizations or individuals, through targeted communication and action, seek to influence citizens for the sake of their good reputation and support, through purposeful communication and action (Lomakina, 2019, 146).

Public communication is the systematic activity of all public sector institutions (president, parliament, government, territorial representations of authorities, courts, attorney general's office, etc.) to pass on to citizens and their associations information on the interpretation of public decisions and reforms, protection and promotion of public rights and values, support for institutional design and social connections, positioning the state for audiences abroad (Lomakina, 2019, P. 146).

The positive effectiveness of communications must be consistent and systematic. Without a systematic approach, systemic success cannot be achieved. This 
should not be a one day event or one single event, but a logical interconnection of communication actions towards positive developments in Ukraine. It is important for most institutions to draw conclusions and transfer the experience of communications and their importance to further management.

Every time we can see the government communications fail, because political communication must be an integral part of government communication. It is crucial to determine the ideology and values we follow, the direction of development and the paths of achievement that will determine the essence of political communication. As for the state communications, it must be a systematic work with the population to clarify, for example, tariffs for housing and communal services, to explain why some issues are considered by the state as a priority at the moment, and why these issues are put into the forefront, why something is happening in a certain way, and not otherwise, it is also a call for the population to join and act as the state considers it necessary.

At present, there is no clear distinction between those responsible for political communications and those responsible for state communications. This is neither at the level of understanding nor at the level of embodiment. However, the functions of political and state communications are quite different. And if the functions of political communication are constant and steady-going, then the functions of state communication change depending on the ruling political elite.

In Ukrainian political realities the question about the role of communication in the system of government raises serious concern. All managers' actions should be explained. The explanations should be designed for the target audience, and even more, they should be based on the opinion of that target audience. That is, any civilized society builds its own policy based on opinion polls to understand what is important for the population at the moment, and then it is necessary to prioritize the issues that need to be addressed first. These should not be issues determined by the interests of the President, but if the issue is proclaimed, then it is necessary to clarify why these issues are in priority and what are the ways to solve them, what are the deadlines, costs, etc. This is the essence of the managerial role of communications: every management decision and its implementation process must be explained.

The problem is that the issues are not resolved, are not clarified and there is no liability for the consequences. That is, mass explanations to the population about certain reforms are not provided, and this, incidentally, is the reason of the defeat of the previous elite, which failed to «sell» the reforms to the population, in other words could not explain them. The new political elite sets itself up differently than its predecessors, but also does not explain its activities. In addition, another aspect of political communication is currently arising - the linguistic competence of the politician, as the manager's purely linguistic abilities, which influence his oratorical skills, his ability to persuade and inspire the public's confidence. 
It is only through knowledge, understanding, acceptance and trust that one can convince the population and win its recognition.

Last, most important. Trust, as a scientific category, has many approaches to consideration, long-established theories and doctrines. German sociologist G. Zimmel, one of the founders of researches on this phenomenon, noted that trust is «one of the most important synthetic forces in society» (Simmel, 1950, P. 326). G. Zimmel also defined trust as «the mean state between knowledge and ignorance» (Simmel, 1968, P. 263).

The approach of N. Luman, who chose the system-theoretical approach to clarify the essence of the concept of «trust», was also interesting. In this approach, trust can be seen as a mechanism that contributes to reducing social complexity or taking a risky step forward.

Political scientist and economist F. Fukuyama defined trust as «an expectation that arises in a community of regular, truthful and collective behavior based on social norms on the part of other members of that community»(Fukuyama, 1996).

Researchers have never come to a united understanding of the universal definition of trust (Mühl, 2014). However, first you need to know what is happening, secondly to understand why everything is happening, thirdly to accept for yourself that it is really needed. To believe that everything that is going to happen will have positive changes for me personally, and only then, it will be possible to gradually build trust in the authorities.

But modern Ukrainian society has no institution that would pass through these stages. «We need to work to ensure that there is a better communication in the country, that our opinion of ourselves is no worse than opinion about us abroad, and that we learn to communicate what we have managed to do» (Bidenko A., 2018) noted Mariana Kaganyak, Ukrainian expert in international economic relations. The majority of the population is not aware of what the European integration will entail for the country, what will entail joining the EU, NATO and others. We've seen only slogans claiming that European integration and NATO are good. Only political communication in the system of country management and its ability to be influential (through linguistic and communication skills, ability to expression's own thoughts) are capable to promote avoiding misunderstandings and conflicts. Therefore, until communication takes a prominent place in the system of country management, further constructive and effective shifts become impossible.

Conclusion. Although communication takes a lot of place in a large number of legislative acts, the word «communication» is not constitutionally mentioned anywhere, but instead there is only information and coverage. Therefore, it is impossible to put into practice something that appears to be nonexistent, that is, what is not in the constitution. For example, it is impossible to create a communication budget because there is no single mechanism that would manage all communications. The country needs to create an institution that deals with the communication of state programs to change the view of those communication reforms that are being implemented. 
Thus, the most important things are: systematic implementation of changes starting from the state constitution in the field of communication management; verbal image of the government official, his linguistic communication to gain the trust of the society; clear explanation of the decisions and reforms that will lead to overall wellbeing and global recognition.

\section{REFERENCES}

1. Bidenko A. (2018). Usya derzhavna komunikaciya maye buty' unifikovanoyu - Bidenko. Retrieved from: https://www.ukrinform.ua/rubric-polytics/ 2600208-usa-derzavna-komunikacia-mae-buti-unifikovanou-bidenko.html [in Ukraine].

2. Fukuyama F. (1996) Trust: Human Nature and the Reconstitution of Social Order. Free Press Paperbacks Books. New York. P. 26.

3. Government Communication Handbook. Government Office. URL: https://www.valitsus.ee/sites/default/files/content-editors/failid/government_ communication_handbook_eng_13.09.2017.pdf

4. Lomakina T. A. (2019) Naukovi pidkhody do vyznachennia poniattia «derzhavna komunikatsiia». Investytsii: praktykata dosvid. № 5. S. 143-151. Retrieved from : DOI: 10.32702/2306-6814.2019.5.143 [in Ukraine].

5. Lee M. (2007) Government public relations. A reader. Boca Raton: CRC Press. $456 \mathrm{p}$.

6. Mühl J. K. (2014). Organizational Trust. Springer International Publishing Switzerland. P. 7.

7. Nicolescu A., Teodorescu M., Gifu D. (2015). Arcitecture of Political Legal Communication. International Letters of Social and Humanistic Sciences. Vol. 42. P. 21-31. Retrieved from URL: https://www.scipress.com/ILSHS.42.21.pdf

8. Pryluts'ka A., Karpenko O., Parafijnyk N., Medved' O. (2016). Dokumentno-informatsij nezabezpechennia suchasnoi profesijnoi komunikatsii: navch. posib. Kharkiv. 360 s. [in Ukraine].

9. Simmel G. (1950). The Sociology of Georg Simmel. Glencoe. Free Press P. 326. Retrieved from : URL: https://archive.org/stream/sociologyofgeorg030082mbp/ sociologyofgeorg030082mbp_djvu.txt

10. Simmel G.(1968). Soziologie. Berlin, P. 263. 